\title{
Anti-obesity effects of boiled tuna extract in mice with obesity induced by a high-fat diet
}

\author{
YOUNGMIN KIM ${ }^{1,2}$, MI-JIN KWON ${ }^{2}$, JEONG-WOOK CHOI ${ }^{1}$, MIN-KYEONG LEE ${ }^{1}$, CHORONG KIM $^{1}$, \\ JAEHUN JUNG $^{1}$, HENY APRIANITA ${ }^{1}$, HEESOP NAM ${ }^{3}$ and TAEK-JEONG NAM ${ }^{1,2}$ \\ ${ }^{1}$ Department of Food Science and Nutrition, Pukyong National University, Busan 608-737; ${ }^{2}$ Institute of Fisheries Science, \\ Pukyong National University, Busan 619-911; ${ }^{3}$ Dongwon F\&B, Seoul 06775, Republic of Korea
}

Received March 23, 2016; Accepted July 27, 2016

DOI: $10.3892 /$ ijmm.2016.2695

\begin{abstract}
The aim of this study was to examine the antiobesity effects of boiled tuna extract in C57BL/6N mice with obesity induced by a high-fat diet (HFD). We determined the anti-obesity effects of boiled tuna extract $(100,200$, or $400 \mathrm{mg}$ / $\mathrm{kg}$ ) on the progression of HFD-induced obesity for 10 weeks. The mice were divided into 5 groups as follows: the normal diet (ND) group $(n=10)$; the HFD group $(n=10)$; the mice fed HFD and $100 \mathrm{mg} / \mathrm{kg}$ boiled tuna extract group $(\mathrm{n}=10)$; those fed a HFD and $200 \mathrm{mg} / \mathrm{kg}$ boiled tuna extract group $(\mathrm{n}=10)$; and those fed a HFD and $400 \mathrm{mg} / \mathrm{kg}$ boiled tuna extract group $(n=10)$. Changes in body weight, fat content, serum lipid levels and lipogenic enzyme levels were measured. The consumption of boiled tuna extract lowered epididymal tissue weight and exerted anti-obesity effects, as reflected by the serum glucose, triglyceride (TG), total cholesterol (TC), high-density lipoprotein cholesterol (HDL-C), low-density lipoprotein cholesterol (LDL-C), insulin and leptin levels. In addition, we demonstrated changes in liver adipogenic- and lipogenic-related protein expression by western blot analysis. Boiled tuna extract downregulated the levels of the CCAAT/enhancer-binding protein $\alpha, \beta$ and $\delta(\mathrm{C} / \mathrm{EBP} \alpha, \beta, \delta)$, and peroxisome proliferator-activated receptor- $\gamma$ (PPAR- $\gamma$ ) adipocyte marker genes. Boiled tuna extract also attenuated adipogenic and lipogenic gene expression, namely the levels of fatty acid synthase (FAS), lipoprotein lipase (LPL), acetyl-CoA carboxylase (ACC), glucose transporter type 4 (Glut4) and phosphorylated adenosine monophosphate-activated protein kinase $\alpha$ and $\beta$ (AMPK $\alpha, \beta)$ in a dose-dependent manner. Moreover, the consumption of boiled tuna extract restored the levels of superoxide dismutase (SOD), catalase (CAT), glutamic oxaloacetic transaminase (GOT), glutamic-pyruvate
\end{abstract}

Correspondence to: Professor Taek-Jeong Nam, Department of Food Science and Nutrition, Pukyong National University, 599-1 Daeyeon 3-dong, Nam-gu, Busan 608-737, Republic of Korea E-mail: namtj@pknu.ac.kr

Key words: CCAAT/enhancer-binding protein $\alpha$, peroxisome proliferator-activated receptor- $\gamma$, anti-obesity, boiled tuna extract, cholesterol transaminase (GPT), aspartate transaminase (AST) and alanine transaminase (ALT) to those of the control group. These results suggest that boiled tuna extract attenuates the progression of obesity by stimulating fatty acid oxidation through the upregulation of AMPK genes, as well as by inhibiting the synthesis of adipogenic and lipogenic enzymes. These characteristics of boiled tuna extract highlight its potential anti-obesity effects.

\section{Introduction}

Obesity is associated with metabolic syndrome, a group of risk factors for cardiovascular disease, type 2 diabetes mellitus (T2DM) and other pathologies, including hypertension, hyperlipidemia, coronary artery disease and cancers $(1,2)$. A worldwide survey conducted in 2013, found that the body mass index (BMI) of adults had increased by $36.9 \%$ in men and by $38.0 \%$ in women (3). Many factors play a role in increasing the prevalence of obesity, including technological developments in the food industry and the prevalence of fast food (4). Moreover, obesity, specifically abdominal obesity, causes serum adipokine imbalance, insulin resistance and endothelial dysfunction (5). It is associated with dyslipidemia as well as an increase in the ratio of total cholesterol (TC) to high-density lipoprotein cholesterol (HDL-C) (6). A study performed on mice determined that the consumption of a highfat diet (HFD) resulted in elevated levels of serum cholesterol and insulin, specifically fasting insulin and pro-insulin (7). Likewise, HFD-fed mice have been shown to have lower superoxide dismutase (SOD) levels compared with normal mice (8), and obese mice have been shown to have increased triglyceride (TG) and glucose levels, and hypertension after 8 weeks on a HFD (9). HFDs are linked with both leptin and insulin resistance (10), and importantly, are associated with hepatic steatosis. Moreover, HFD-fed mice had increased levels of serum glutamic oxaloacetic transaminase (GOT) and glutamic-pyruvate transaminase (GPT) compared with mice fed a normal diet (ND) and those fed HFD supplemented with $\alpha$-lipoic acid for 24 weeks (11). In addition, it has been shown that HFD-fed mice have greater adipocyte hypertrophy and increased levels of inflammatory cytokines [monocyte chemoattractant protein (MCP)-1 and tumor necrosis factor (TNF)- $\alpha$ ], as well as hepatic steatosis (12). Catalase (CAT) activity is significantly upregulated after the consumption of a HFD; an 
increased CAT protein content translates to increased enzyme activity in the mouse heart (13).

Tuna contains bioactive peptides formed from enzymatically hydrolyzed byproducts (14). Hydrolyzed byproducts from tuna dark muscle have been shown to exert anticancer effects on $\mathrm{MCF}-7$ cells, with peptide fractions ranging from 390 to $1400 \mathrm{Da}$, having the highest anti-proliferative activity (15).

Previous studies using western blot analysis have revealed the anti-obesity effects of peptides derived from tuna proteins, which have been shown to significantly reduce the expression levels of the adipocyte marker genes, CCAAT/enhancer-binding protein $(\mathrm{C} / \mathrm{EBP}) \alpha$ and peroxisome proliferator-activated receptor- $\gamma$ (PPAR- $\gamma$ ) (16). Moreover, these results were supported by the upregulation of Wnt-10b mRNA expression and the activation of the Wnt signaling pathway in 3T3-L1 adipocyte cells (17). The Wnt signaling pathway plays a key role in the differentiation of adipocytes and downregulates the expression of adipocyte-specific genes (18). A previous study demonstrated that the peptides present in boiled tuna extract inhibit the differentiation of 3T3-L1 cells in vitro, and highlighted the effectiveness of this model for metabolism and obesity research (17). Moreover, these peptides can decrease the expression levels of adipogenic genes $(17,18)$. Based on these data, we were interested in exploring the anti-obesity effects of boiled tuna extract in vivo in $\mathrm{C} 57 \mathrm{BL} / 6 \mathrm{~N}$ mice. We hypothesized that tuna may improve body weight and affect metabolic systems. In this study, using serum and western blot analyses, we identified the genes responsible for the effects of tuna extract on obesity. Blood and liver tissues were assessed in order to measure the levels of TC, HDL-C, low-density lipoprotein cholesterol (LDLC), insulin, leptin, TG, glucose, CAT, SOD, GOT, GPT, aspartate transaminase (AST) and alanine transaminase (ALT).

\section{Materials and methods}

Preparation of boiled tuna extract. The desalinated boiled tuna extract used was prepared in Korea in 2015. First, boiled tuna extract was centrifuged $\left(10,000 \mathrm{rpm}, 30 \mathrm{~min}, 22^{\circ} \mathrm{C}\right)$ to remove any suspended solids that may interfere with the desalting step. This process involves a change from 55 Brix, 13\% salinity to 45 Brix, $12 \%$ salinity. We performed membrane filtration (membrane 2319/size $200 \mathrm{Da}$ ) on the desalinated boiled tuna extract. We finally obtained a tuna extract of 30 Brix, $1 \%$ salinity, which was subjected to heat exchanger-type momentary sterilization (conditions: $110^{\circ} \mathrm{C}, 10 \mathrm{sec}$ ). The tuna extract sample was then transferred to $1.5 \mathrm{ml}$ tubes and stored at $-70^{\circ} \mathrm{C}$ until use.

Animals and diets. Male 5-week-old C57BL/6N mice were purchased from Samtako Bio Korea Co. (Gyeonggi-do, Korea). The animal care and use protocol in this study was approved by the Institutional Animal Care and Use Committee (IACUC) of Pukyong National University, Busan, Korea (Approval no. 2015-04). They were maintained on a 12-h light-dark cycle for 1 week prior to the experiments, and were housed in cages under controlled room temperature $\left(22 \pm 2^{\circ} \mathrm{C}\right)$ and humidity $(55 \pm 5 \%)$. Mice had ad libitum access to a commercially available diet (Samtako Bio Korea Co.) and water. After 1 week, the feed was changed to the AIN-76 semi-purified diet (MP0290545220; MP Biomedicals, LLC, Solon, OH, USA) with added lard and corn oil to induce obesity for 10 weeks. The mice were divided into 5 groups as follows: i) the ND group $(n=10)$; the ii) HFD group $(\mathrm{n}=10)$; iii) the group fed a HFD and $100 \mathrm{mg} /$ $\mathrm{kg}$ boiled tuna extract (HFD + T100) $(\mathrm{n}=10)$; iv) mice fed a HFD and $200 \mathrm{mg} / \mathrm{kg}$ boiled tuna extract (HFD + T200) $(\mathrm{n}=10)$; and v) the group fed a HFD and $400 \mathrm{mg} / \mathrm{kg}$ boiled tuna extract group (HFD + T400) $(n=10)$. The diet composition is shown in Table I.

Analysis of blood. Mice were anesthetized with ether, and blood was obtained by the intraorbital vein collection method. Blood samples were centrifuged at 2,500 $\mathrm{x} \mathrm{g}$ for $15 \mathrm{~min}$ at $4^{\circ} \mathrm{C}$, and subsequently stored at $-70^{\circ} \mathrm{C}$. Enzyme kits were used to measure the serum levels of TC, HDL-C, TG, glucose (Asan Pharmaceutical Co., Ltd., Gyeonggi, Korea), LDL-C (Cusabio Biotech Co., Ltd., Wuhan, China), leptin (Enzo Life Sciences, Inc., Farmingdale, NY, USA), insulin (Alpco Diagnostics, Windham, NH, USA), ALT and AST (both from Sigma-Aldrich, St. Louis, MO, USA), according to the manufacturer's instructions at an absorbance of $490 \mathrm{~nm}$ using a Benchmark enzyme-linked immunosorbent assay (ELISA) plate reader (Bio-Rad Laboratories, Hercules, CA, USA).

Analysis of liver tissue. Mice were anesthetized with ether, and liver tissues were obtained. Liver tissue samples $(0.2 \mathrm{~g})$ were homogenized in $1 \mathrm{ml}$ of phosphate-buffered saline (PBS), and the samples were centrifuged at $2,500 \mathrm{x}$ g for $15 \mathrm{~min}$ at $4^{\circ} \mathrm{C}$ and stored at $-70^{\circ} \mathrm{C}$. The levels of CAT, SOD (Arbor Assays, Ann Arbor, MI, USA), GOT and GPT (Asan Pharmaceutical Co., Ltd.) were measured using enzyme kits, according to the manufacturer's instructions at an absorbance at $490 \mathrm{~nm}$ using a Benchmark ELISA plate reader (Bio-Rad Laboratories).

Western blot analysis. The liver tissues were washed with PBS and lysis buffer [20 mM Tris base (pH 8.0), $150 \mathrm{mM} \mathrm{NaCl}$, $100 \mu \mathrm{M}$ sodium vanadate, $100 \mu \mathrm{M}$ ammonium molybdate, $10 \%$ (v/v) glycerol, $0.1 \%$ (v/v) Nonidet P-40, 0.1\% (w/v) SDS, $1 \mathrm{mM}$ glycerophosphate, $1 \mu \mathrm{g} / \mathrm{ml}$ aprotinin, $1 \mu \mathrm{g} / \mathrm{ml}$ leupeptin, $1 \mu \mathrm{g} / \mathrm{ml}$ pepstatin $\mathrm{A}$, and $1 \mathrm{mM}$ phenylmethanesulfonyl fluoride (PMSF)] was added. Proteins were separated by $7-15 \%(\mathrm{w} / \mathrm{v})$ SDS-PAGE and transferred onto polyvinylidene fluoride membranes (Millipore, Billerica, MA, USA). The membranes were blocked at room temperature with $1 \%(\mathrm{w} / \mathrm{v})$ bovine serum albumin in TBS-T [10 mM Tris-HCl (pH 7.5), $150 \mathrm{mM} \mathrm{NaCl}, 0.1 \%$ (v/v) Tween-20] and incubated on a shaker with the following antibodies: anti-C/EBP $\alpha$ (sc-9314, anti-rabbit; 1:1,000), anti-C/EBP $\beta$ (sc-150, anti-rabbit; 1:1,000), anti-C/EBPS (sc-151, anti-rabbit; 1:1,000), anti-PPAR- $\gamma$ (sc-1984, anti-goat; 1:1,000), anti-CD36 (sc-7641, anti-goat; 1:1,000), anti-lipoprotein lipase (LPL) (sc-32382, anti-goat; 1:1,000), anti-sterol regulatory element-binding protein-1 (SREBP-1) (sc-366, anti-rabbit; 1:1,000), anti-fatty acid synthase (FAS) (sc-7886, anti-mouse; 1:1,000), anti-acetyl-CoA carboxylase (ACC) (sc-271965, anti-mouse; 1:1,000), anti-fatty acid binding protein (FABP) (sc-18661, anti-goat; 1:1,000), anti-glucose transporter type 4 (Glut4) (sc-1606, anti-goat; 1:1,000), anti-glyceraldehyde 3-phosphate dehydrogenase (GAPDH) (sc-25778, anti-rabbit; 1:1,000) (all from Santa 
Table I. Composition of the experimental diets $(\mathrm{mg} / \mathrm{kg} / \mathrm{day})$.

\begin{tabular}{|c|c|c|c|c|c|}
\hline Component & Control & HFD & $\mathrm{HFD}+\mathrm{T} 100$ & $\mathrm{HFD}+\mathrm{T} 200$ & $\mathrm{HFD}+\mathrm{T} 400$ \\
\hline Casein & 875.0 & 742.0 & 741.1 & 741.1 & 741.1 \\
\hline DL-methionine & 13.1 & 11.1 & 11.1 & 11.1 & 11.1 \\
\hline Sucrose & 2187.5 & 1855 & 1852.8 & 1852.8 & 1852.8 \\
\hline Corn starch & 656.3 & 556.5 & 555.8 & 555.8 & 555.8 \\
\hline Cellulose & 218.8 & 185.5 & 185.3 & 185.3 & 185.3 \\
\hline Corn oil & 218.8 & 185.5 & 185.3 & 185.3 & 185.3 \\
\hline Mineral mix & 153.1 & 129.9 & 129.7 & 129.7 & 129.7 \\
\hline Vitamin mix & 43.8 & 37.1 & 37.1 & 37.1 & 37.1 \\
\hline Choline bitartate & 8.8 & 7.4 & 7.4 & 7.4 & 7.4 \\
\hline Lard & 0 & 630.7 & 630.0 & 630.0 & 630.0 \\
\hline Cholesterol & 0 & 37.1 & 37.1 & 37.1 & 37.1 \\
\hline Boiled tuna powder & 0 & 0 & 4.375 & 8.75 & 17.5 \\
\hline Total & 4375.0 & 4377.8 & 4377.0 & 4381.4 & 4390.1 \\
\hline Calories & 16843.8 & 19959.8 & 19936.3 & 19936.3 & 19936.3 \\
\hline Fat & 1968.8 & 7345.8 & 7337.1 & 7337.1 & 7337.1 \\
\hline Fat (\% calorie) & 11.7 & 36.8 & 36.8 & 36.8 & 36.8 \\
\hline
\end{tabular}

HFD, high-fat diet. Control mice were fed a normal diet. HFD + T100, mice fed the HFD and $100 \mathrm{mg} / \mathrm{kg}$ of tuna extract; HFD + T200, mice fed the HFD and $200 \mathrm{mg} / \mathrm{kg}$ of tuna extract; HFD + T400, mice fed the HFD and $400 \mathrm{mg} / \mathrm{kg}$ of tuna extract.

Cruz Biotechnology, Inc., Santa Cruz, CA, USA). The secondary antibodies used were peroxidase-conjugated goat (sc-2741), mouse (sc-2032), or rabbit (sc-2031) antibodies (1:10,000; all from GE Healthcare Bio-Sciences, Piscataway, NJ, USA). Proteins were visualized using the SuperSignal West Pico Stable Peroxide solution and the SuperSignal West Pico Luminol/ Enhancer solution (both from Thermo Fisher Scientific, Inc., Rockford, IL, USA) and Kodak X-ray film.

Statistical analysis. The data are expressed as the means \pm standard deviation(SD). The SPSS software (version 10.0; SPSS,Inc., Chicago, IL, USA) was used to perform all statistical analyses. Comparisons were made using analysis of variance (ANOVA) and Duncan's multiple range test. The level of significance was set at $\mathrm{P}<0.05$.

\section{Results}

Mouse body, adipose tissue and liver weight. At the end of the experimental period, the body weight, liver weight and epididymal and abdominal adipose tissue weights of the mice were measured.

After 10 weeks of consuming the HFD, the body weights of the mice in the groups fed the HFD and tuna extract significantly decreased compared with those of the mice fed the HFD and not fed the tuna extract. Moreover, the epididymal adipose tissue weight of the mice fed the HFD and $100 \mathrm{mg} / \mathrm{kg}$ boiled tuna extract group was slightly decreased, and that of the HFD-fed mice given 200 and $400 \mathrm{mg} / \mathrm{kg}$ of tuna extract was decreased to levels similar to those of the mice in the ND group. The abdominal adipose tissue weight significantly decreased in the mice fed the HFD and $200 \mathrm{mg} / \mathrm{kg}$ and $400 \mathrm{mg} / \mathrm{kg}$ of boiled tuna extract, while no significant changes were observed in that of mice fed the HFD and $100 \mathrm{mg} / \mathrm{kg}$ of tuna extract. The liver weight of all mice fed the boiled tuna extract was significantly decreased compared with the mice fed the HFD and not given the tuna extract (Table II).

Effects of boiled tuna extract on serum enzyme levels in mice fed a HFD. Leptin is secreted by adipocytes, and its functions are to regulate appetite and energy metabolism, resulting in satiety. It is also directly related to insulin resistance and body fat content (19). An increase in serum TG levels is associated with a risk of heart disease (20). In general, high concentrations of TG result in the accumulation of TC, and LDL-C can build up on artery walls (21). However, increased HDL-C levels attenuate the accumulation of LDL-C and protect against heart disease by transporting LDL-C, TC and TG from the arteries (22). Generally, glucose levels are increased in obesity and result in increased TC and TG levels (17). In this study, we observed increased glucose and TG serum levels in mice fed a HFD. However, the glucose and TG levels were significantly decreased in all the groups fed the HFD and the tuna extract [glucose: ND (control, con), 121.4 $\pm 19.4 \mathrm{mg} / \mathrm{dl}$; HFD, $152.6 \pm 32.5 \mathrm{mg} / \mathrm{dl} ; \mathrm{HFD}+\mathrm{T} 100,127.8 \pm 27.0 \mathrm{mg} / \mathrm{dl} ; \mathrm{HFD}+\mathrm{T} 200$, $116.2 \pm 19.5 \mathrm{mg} / \mathrm{dl} ; \mathrm{HFD}+\mathrm{T} 400,119.1 \pm 16.0 \mathrm{mg} / \mathrm{dl} ; \mathrm{TG}$ : ND, 90.4 $\pm 9.1 \mathrm{mg} / \mathrm{dl} ; \mathrm{HFD}, 119.5 \pm 23.4 \mathrm{mg} / \mathrm{dl} ; \mathrm{HFD}+\mathrm{T} 100$, 127.86.1 $\pm 19.1 \mathrm{mg} / \mathrm{dl} ; \mathrm{HFD}+\mathrm{T} 200,86.3 \pm 23.5 \mathrm{mg} / \mathrm{dl}$; HFD + T400,90.7 $\pm 10.6 \mathrm{mg} / \mathrm{dl}$ ] (Fig. 1). Additionally, the TC and LDL-C levels were significantly decreased in all the groups fed the HFD and the tuna extract (TC: ND, $135.0 \pm 17.5 \mathrm{mg} / \mathrm{dl}$; HFD, $199.2 \pm 12.1 \mathrm{mg} / \mathrm{dl} ; \mathrm{HFD}+\mathrm{T} 100,166.5 \pm 14.8 \mathrm{mg} / \mathrm{dl} ; \mathrm{HFD}+\mathrm{T} 200$, $163.6 \pm 20.2 \mathrm{mg} / \mathrm{dl} ; \mathrm{HFD}+\mathrm{T} 400,152.6 \pm 7.2 \mathrm{mg} / \mathrm{dl} ; \mathrm{LDL}-\mathrm{C}$ : $\mathrm{ND}, 21.5 \pm 2.7 \mathrm{mg} / \mathrm{dl}$; HFD, 34.6 $\pm 3.3 \mathrm{mg} / \mathrm{dl} ; \mathrm{HFD}+\mathrm{T} 100$, $28.2 \pm 4.6 \mathrm{mg} / \mathrm{dl} ; \mathrm{HFD}+\mathrm{T} 200,28.6 \pm 4.1 \mathrm{mg} / \mathrm{dl} ; \mathrm{HFD}+\mathrm{T} 400$, $26.4 \pm 3.4 \mathrm{mg} / \mathrm{dl})$. However, the HDL-C levels were only increased 
Table II. Body, liver, and epididymal and abdominal adipose tissue weights in mice fed a HFD and boiled tuna extract for 10 weeks.

Weight (g)

\begin{tabular}{lcccc}
\cline { 2 - 4 } Group & Body & Liver & Epididymal fat & $\begin{array}{c}\text { Abdominal } \\
\text { subcutaneous fat }\end{array}$ \\
\hline Control & $31.51 \pm 2.41^{\mathrm{a}}$ & $1.09 \pm 0.11^{\mathrm{a}}$ & $0.83 \pm 0.23^{\mathrm{a}}$ & $0.43 \pm 0.15^{\mathrm{a}}$ \\
HFD & $34.51 \pm 2.43^{\mathrm{b}}$ & $1.50 \pm 1.15^{\mathrm{c}}$ & $1.45 \pm 0.28^{\mathrm{c}}$ & $0.88 \pm 0.27^{\mathrm{b}}$ \\
HFD + T100 $(\mathrm{mg} / \mathrm{kg})$ & $32.10 \pm 0.31^{\mathrm{a}}$ & $1.30 \pm 0.22^{\mathrm{b}}$ & $1.13 \pm 0.31^{\mathrm{b}}$ & $0.74 \pm 0.31^{\mathrm{b}}$ \\
HFD + T200 $(\mathrm{mg} / \mathrm{kg})$ & $31.30 \pm 2.04^{\mathrm{a}}$ & $1.20 \pm 0.12^{\mathrm{a}, \mathrm{b}}$ & $0.86 \pm 0.24^{\mathrm{a}}$ & $0.48 \pm 0.20^{\mathrm{a}}$ \\
HFD + T400 $(\mathrm{mg} / \mathrm{kg})$ & $30.96 \pm 1.72^{\mathrm{a}}$ & $1.08 \pm 0.87^{\mathrm{a}}$ & $0.79 \pm 0.27^{\mathrm{a}}$ & $0.43 \pm 0.23^{\mathrm{a}}$ \\
\hline
\end{tabular}

HFD, high-fat diet. HFD + T100, mice fed the HFD and $100 \mathrm{mg} / \mathrm{kg}$ of tuna extract; HFD + T200, mice fed the HFD and $200 \mathrm{mg} / \mathrm{kg}$ of tuna extract; HFD + T400, mice fed the HFD and $400 \mathrm{mg} / \mathrm{kg}$ of tuna extract. Values marked with different lower case letters in superscript format indicate significant differences; values marked with the same lower case letters in superscript format indicate no significant differences.
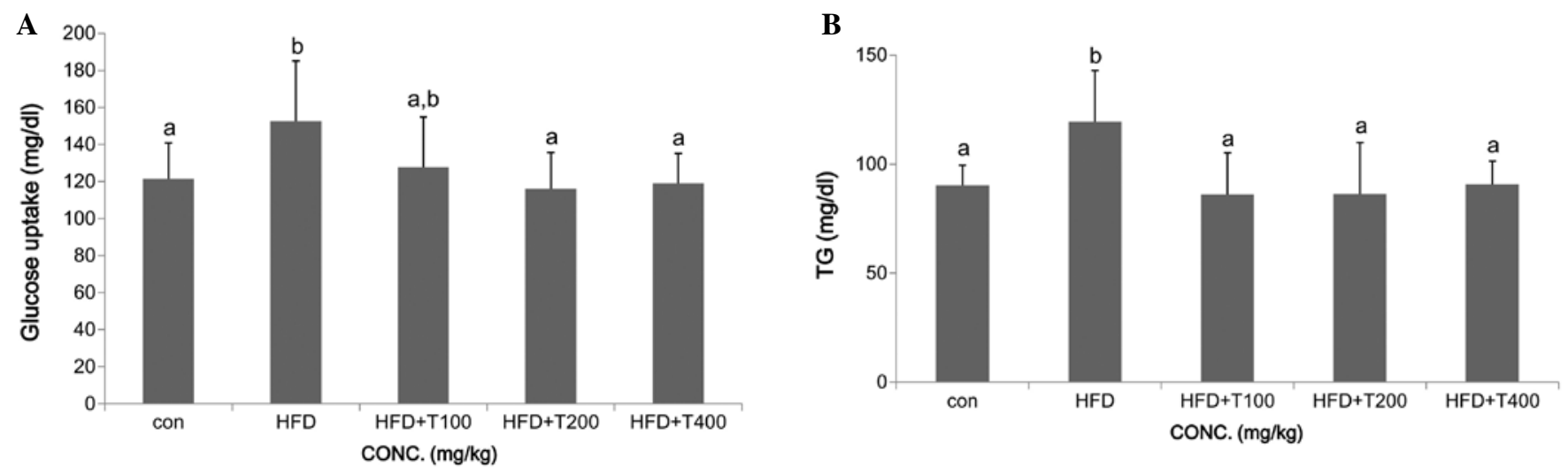

Figure 1. Effects of boiled tuna extract on serum glucose and triglyceride (TG) concentrations in mice fed a high-fat diet (HFD). (A) Glucose and (B) TG concentrations. $\mathrm{P}<0.05$. Values are shown as the means \pm SD. Data were analyzed using ANOVA. Bars marked with different lower case letters indicate significant differences; bars marked with the same lower case letters indicate no significant differences. Control (con) mice were fed a normal diet (ND).

in the group fed the HFD and $400 \mathrm{mg} / \mathrm{kg}$ of the boiled tuna extract (HDL-C: ND, 73.2 $\pm 5.7 \mathrm{mg} / \mathrm{dl}$; HFD, 95.5 $\pm 11.8 \mathrm{mg} / \mathrm{dl}$; HFD + T100, 101.5 $\pm 5.1 \mathrm{mg} / \mathrm{dl} ; \mathrm{HFD}+\mathrm{T} 200,105.2 \pm 14.0 \mathrm{mg} / \mathrm{dl}$; HFD + T400, 121.3 $\pm 11.3 \mathrm{mg} / \mathrm{dl}$ ) (Fig. 2A). The serum insulin levels deceased significantly in a dose-dependent manner in the HFD-fed mice given 100, 200, and $400 \mathrm{mg} / \mathrm{kg}$ of the boiled tuna extract, and the leptin levels were significantly decreased in the mice fed HFD and 200 and $400 \mathrm{mg} / \mathrm{kg}$ of the boiled tuna extract (insulin: ND, $0.87 \pm 0.17 \mathrm{ng} / \mathrm{ml}$; HFD, $1.76 \pm 0.26 \mathrm{ng} / \mathrm{ml}$; HFD + T100, $1.51 \pm 0.32 \mathrm{ng} / \mathrm{ml} ; \mathrm{HFD}+\mathrm{T} 200,1.48 \pm 0.32 \mathrm{ng} / \mathrm{ml}$; HFD + T400, $1.27 \pm 0.39 \mathrm{ng} / \mathrm{ml}$; leptin: ND, $2.2 \pm 1.3 \mathrm{ng} / \mathrm{ml}$; HFD, $12.0 \pm 2.3 \mathrm{ng} / \mathrm{ml} ; \mathrm{HFD}+\mathrm{T} 100,11.0 \pm 2.3 \mathrm{ng} / \mathrm{ml} ; \mathrm{HFD}+\mathrm{T} 200$, $8.0 \pm 1.9 \mathrm{ng} / \mathrm{ml}$; HFD + T400, 7.8 $\pm 1.7 \mathrm{ng} / \mathrm{ml}$ ) (Fig. 3). To determine the damaging effects of HFD on the liver, the levels of ALT and AST were measured. The levels of ALT and AST were significantly elevated in the HFD-fed mice compared with the mice fed the ND. However, in all the mice fed the boiled tuna extract, the levels of ALT and AST decreased, and in particular, in the mice fed $400 \mathrm{mg} / \mathrm{kg}$ of the tuna extract, the levels of ALT and AST reached levels similar to those of the control ND-fed mice (Fig. 4).
Effects of boiled tuna extract on liver tissue enzyme levels. After blood collection, the livers of all the mice were removed and weighed immediately. CAT, an enzyme that plays a role in the reduction of hydrogen peroxide with water, forms an antioxidant enzyme system with SOD. In general, increases in various metabolic processes induce oxidative stress and activate SOD and CAT (23); in obesity, the levels of these enzymes are decreased (24). In this study, the SOD and CAT levels in the livers of the mice in all groups are shown in Fig. 5. Consumption of the HFD resulted in impaired protection of the liver and decreased SOD and CAT levels, whereas the consumption of the tuna extract increased the SOD and CAT levels (SOD: ND, 0.18 $\pm 0.04 \mathrm{U} / \mathrm{ml}$; HFD, $0.15 \pm 0.02 \mathrm{U} / \mathrm{ml}$; $\mathrm{HFD}+\mathrm{T} 100,0.16 \pm 0.04 \mathrm{U} / \mathrm{ml} ; \mathrm{HFD}+\mathrm{T} 200,0.18 \pm 0.02 \mathrm{U} / \mathrm{ml}$; HFD + T400, 0.15 $\pm 0.03 \mathrm{U} / \mathrm{ml}$; CAT: ND, $1.33 \pm 0.35 \mathrm{U} / \mathrm{ml}$; HFD, $0.98 \pm 0.14 \mathrm{U} / \mathrm{ml} ; \mathrm{HFD}+\mathrm{T} 100,1.34 \pm 0.30 \mathrm{U} / \mathrm{ml} ; \mathrm{HFD}+\mathrm{T} 200$, $1.38 \pm 0.22 \mathrm{U} / \mathrm{ml}$; HFD + T400, $1.43 \pm 0.35 \mathrm{U} / \mathrm{ml})$. Moreover, the consumption of a HFD can result in hepatic steatosis (25). In our study, the mice fed the HFD exhibited increased serum levels of GOT and GPT compared with the ND-fed group, whereas the GOT and GPT levels in the HFD-fed mice given 

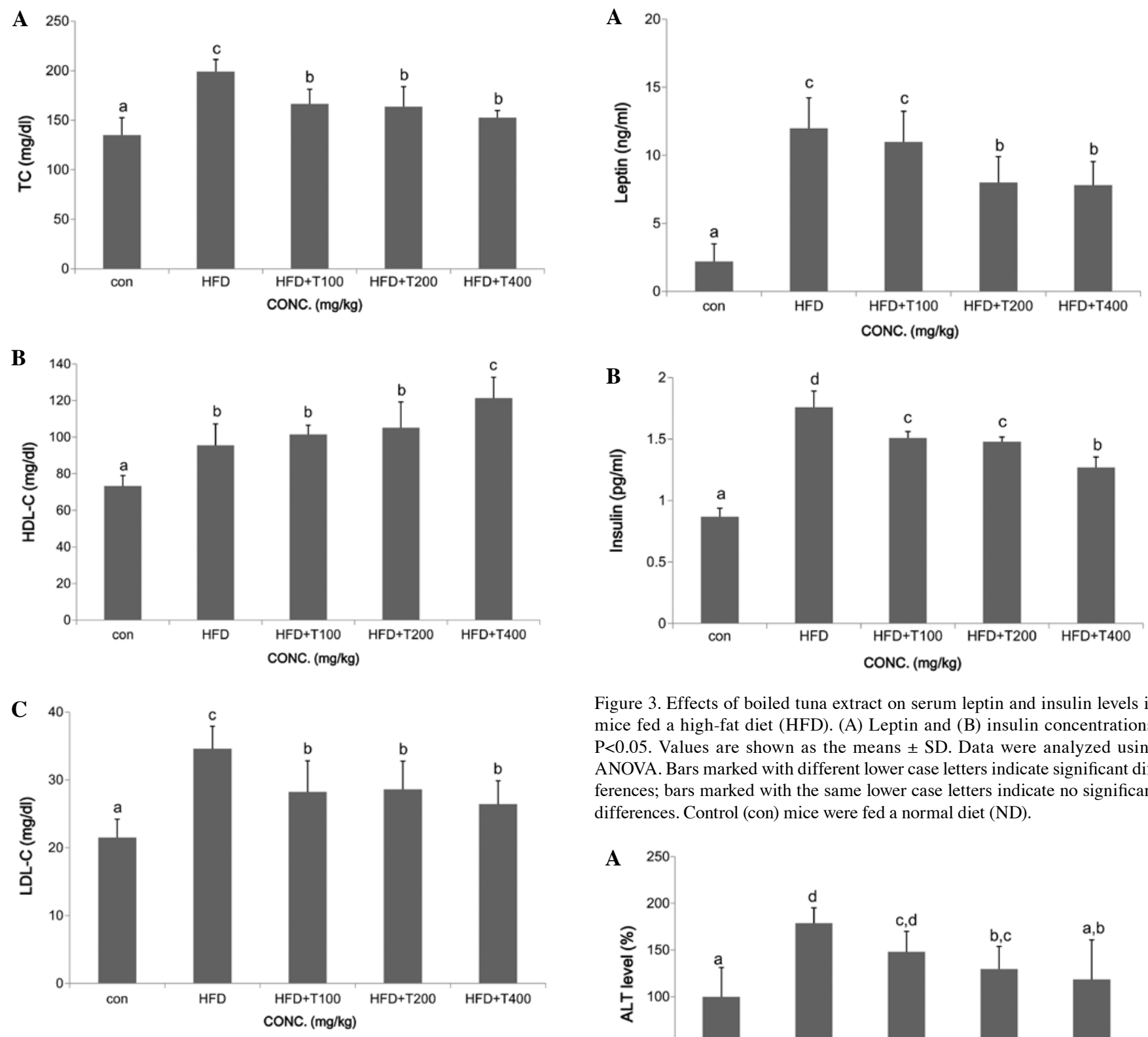

Figure 3. Effects of boiled tuna extract on serum leptin and insulin levels in mice fed a high-fat diet (HFD). (A) Leptin and (B) insulin concentrations. $\mathrm{P}<0.05$. Values are shown as the means $\pm \mathrm{SD}$. Data were analyzed using ANOVA. Bars marked with different lower case letters indicate significant differences; bars marked with the same lower case letters indicate no significant differences. Control (con) mice were fed a normal diet (ND).

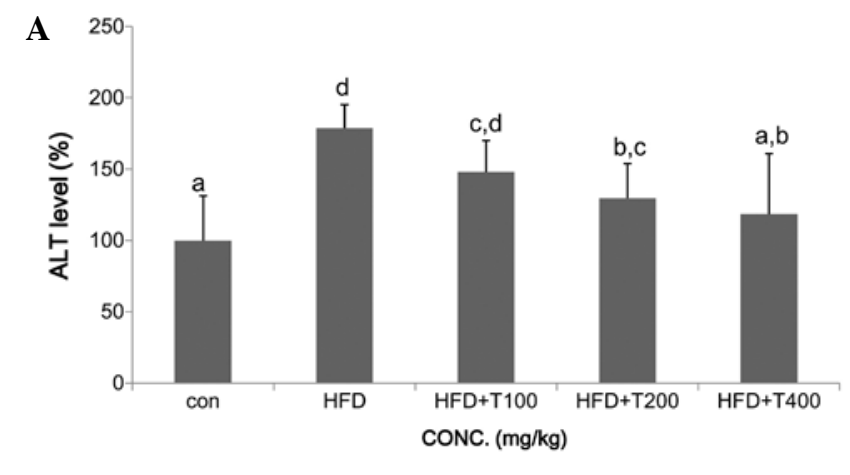

2. Effects of boiled tuna extract on serum total cholesterol (TC), high-density lipoprotein cholesterol (HDL-C) and low-density lipoprotein cholesterol (LDL-C) levels in mice fed a high-fat diet (HFD). (A) TC, (B) HDL-C, and (C) LDL-C concentrations. $\mathrm{P}<0.05$. Values are shown as the means \pm SD. Data were analyzed using ANOVA. Bars marked with different lower case letters indicate significant differences; bars marked with the same lower case letters indicate no significant differences. Control (con) mice were fed a normal diet (ND).

the boiled tuna extract were decreased compared with the HFD-fed group. However, the decrease in the GTP levels was not significant in the mice fed $100 \mathrm{mg} / \mathrm{kg}$ of the tuna extract (GOT: ND, 33.7 $\pm 8.1 \mathrm{IU} / 1$; HFD, 45.2 $\pm 8.7 \mathrm{IU} / \mathrm{l} ; \mathrm{HFD}+\mathrm{T} 100$, 36.4 $\pm 6.6 \mathrm{IU} / 1 ; \mathrm{HFD}+\mathrm{T} 200,36.7 \pm 7.2 \mathrm{IU} / \mathrm{l} ; \mathrm{HFD}+\mathrm{T} 400$, $30.7 \pm 9.3 \mathrm{IU} / 1$; GPT: ND, 30.4 $\pm 4.0 \mathrm{IU} / 1 ; \mathrm{HFD}, 44.7 \pm 11.1 \mathrm{IU} / \mathrm{l}$; HFD + T100, 44.6 $\pm 10.0 \mathrm{IU} / \mathrm{l} ; \mathrm{HFD}+\mathrm{T} 200,40.3 \pm 9.8 \mathrm{IU} / \mathrm{l}$; HFD + T400, 38.7 \pm 6.2 IU/l) (Fig. 6).

Expression levels of lipogenic- and adipogenic-related genes in the liver tissue of mice fed a HFD. To elucidate the mechanisms underlying the effects of boiled tuna extract on lipid metabolism, the levels of lipogenic- and adipogenic-

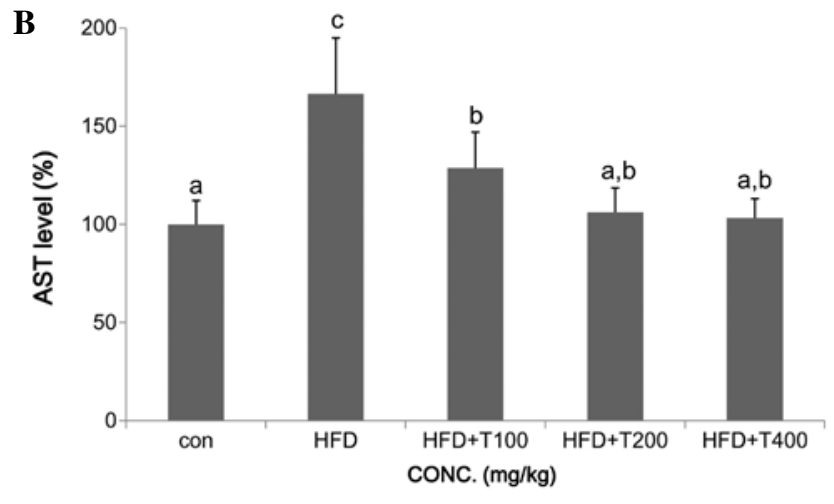

Figure 4. Effects of boiled tuna extract on serum alanine transaminase (ALT) and aspartate transaminase (AST) levels in mice fed a high-fat diet (HFD). (A) ALT and (B) AST levels. P $<0.05$. Values are shown as the means \pm SD. Data were analyzed using ANOVA. Bars marked with different lower case letters indicate significant differences; bars marked with the same lower case letters indicate no significant differences. Control (con) mice were fed a normal diet (ND). 

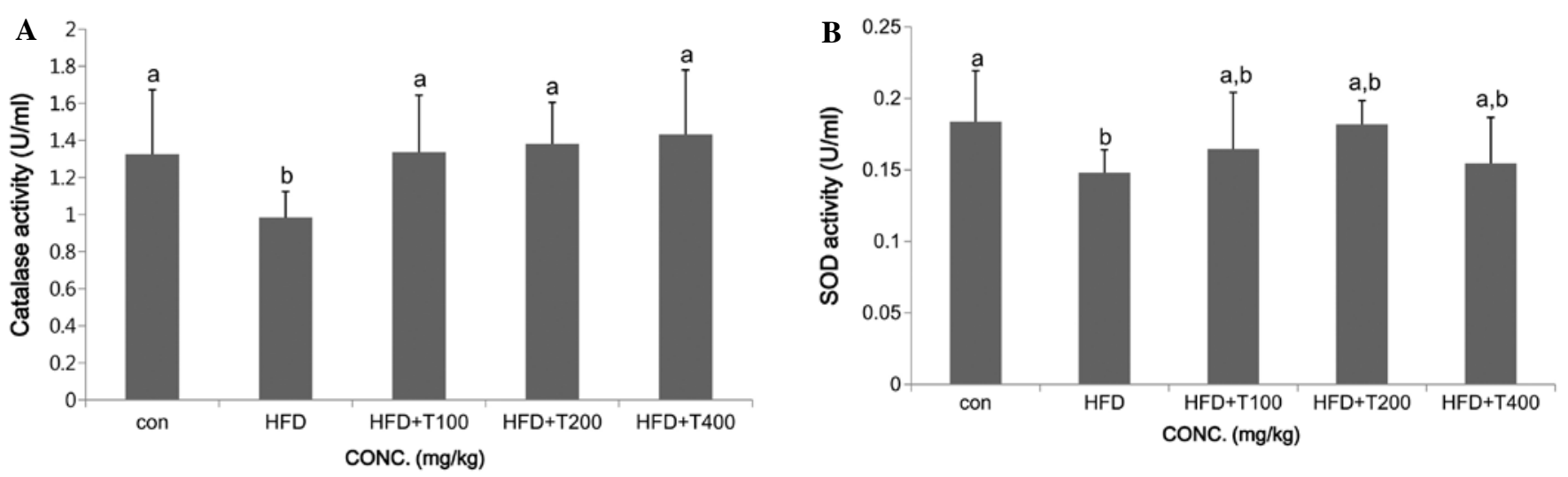

Figure 5. Effects of boiled tuna extract on hepatic superoxide dismutase (SOD) and catalase (CAT) levels in mice fed a high-fat diet (HFD). (A) SOD and (B) CAT levels. $\mathrm{P}<0.05$. Values are shown as the means \pm SD. Data were analyzed using ANOVA. Bars marked with different lower case letters indicate significant differences; bars marked with the same lower case letters indicate no significant differences. Control (con) mice were fed a normal diet (ND).
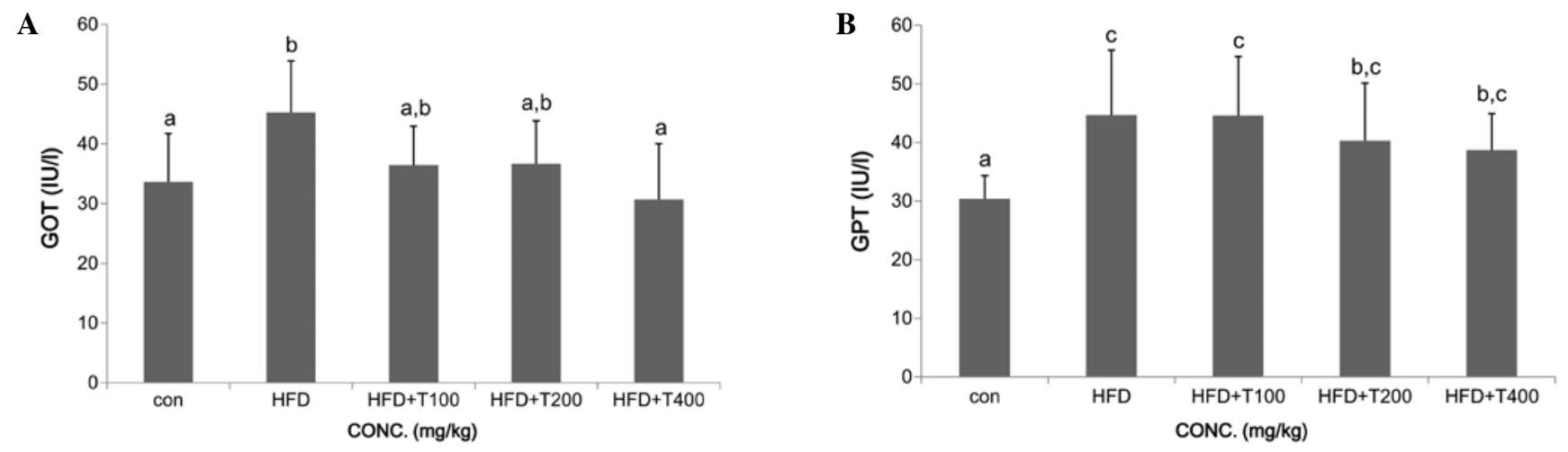

Figure 6. Effects of boiled tuna extract on hepatic glutamic oxaloacetic transaminase (GOT) and glutamic-pyruvate transaminase (GPT) levels in mice fed a high-fat diet (HFD). (A) Alanine transaminase (ALT) and (B) aspartate transaminase (AST) levels. P $<0.05$. Values are shown as the means \pm SD. Data were analyzed using ANOVA. Bars marked with different lower case letters indicate significant differences; bars marked with the same lower case letters indicate no significant differences. Control (con) mice were fed a normal diet (ND).
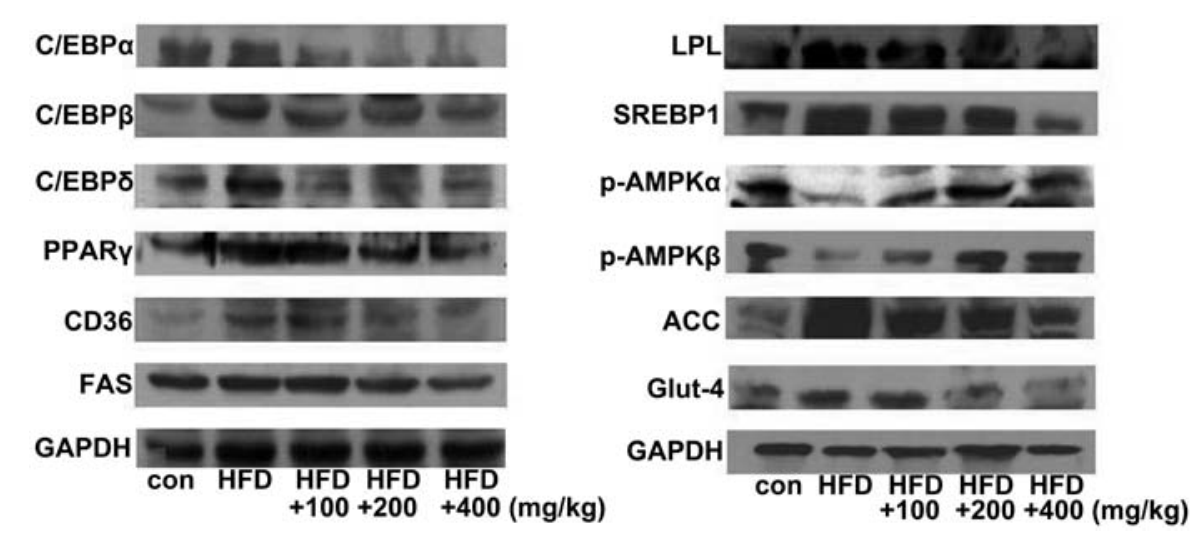

Figure 7. Hepatic expression levels of adipogenesis- and lipogenesis-related proteins following 10 weeks of being fed a high-fat diet (HFD) and boiled tuna extract $(100,200$, and $400 \mathrm{mg} / \mathrm{kg}$ ). Protein expression levels were measured by western blot analysis. Control (con) mice were fed a normal diet (ND).

related genes in liver tissue were measured. Compared with the ND-fed control group, the HFD group exhibited increased expression levels of adipocyte markers, such as C/EBP $\alpha$, C/EBP $\beta$, C/EBPS, PPAR- $\gamma$, CD36, SREBP-1, LPL and FAS. However, the expression levels of these genes were significantly decreased in the mice fed the HFD and boiled tuna extract. The activation of adenosine monophosphate-activated protein kinase $\alpha$ and $\beta$ (AMPK $\alpha, \beta$ ) inhibits the expression of adipogenic-related genes, including ACC and SREBP (26). In this study, AMPK expression was downregulated in the HFD-fed mice, whereas it was upregulated in the mice fed the HFD and boiled tuna extract. Glut4 is involved in the active transport of glucose and is upregulated by C/EBPs and is inhibited in conditions of insulin resistance via the inhibition of C/EBPs 
and PPAR- $\gamma$. In this study, we confirmed the downregulation of Glut 4 by the inhibition of C/EBPs by treatment with tuna extract. Our data clearly demonstrated the downregulation of C/EBPs and Glut4, and the inhibition of lipogenic- and adipogenic-related genes in the mice fed the HFD and various concentrations of the tuna extract (Fig. 7).

\section{Discussion}

Obesity is associated with many pathologies, including metabolic disease, hypertension, atherosclerosis and an increased risk of death from environmental pollution, irregular eating habits and the globalization of fast food (27). Many studies have focused on strategies with which to exert anti-obesity effects by inhibiting the lipogenic and adipogenic pathways. In previous studies, we demonstrated the anti-obesity effects of peptides from boiled tuna extract in 3T3-L1 mouse adipocytes $(16,17)$. In this study, we examined these effects in vivo by administering boiled tuna extract $(100,200$, or $400 \mathrm{mg} /$ $\mathrm{kg}$ ) to C57BL/6N mice with obesity induced by being fed a HFD for 10 weeks. Our data clearly demonstrated that when the HFD-fed mice were fed various concentrations of tuna extract, the body, liver, and epidydimal and abdominal fat weights decreased (Table I). Moreover, tuna is a high source of protein and contains nutritional components that affect atherosclerosis by decreasing serum cholesterol levels. The TC, HDL-C, and LDL-C levels in the mice fed the tuna extract are shown in Fig. 1. Both the TC and LDL-C levels decreased in a dose-dependent manner in the mice fed the HFD and boiled tuna extract compared with the HFD-fed group. However, the HDL-C levels only increased significantly in the mice fed the a tuna extract at a dose of $400 \mathrm{mg} / \mathrm{kg}$ (Fig. 2).

Leptin is a key adipose-derived regulator of energy expenditure and food intake, and its secretion levels are positively associated with the extent of TG stores in adipose tissue (28). Additionally, changes in insulin secretion occur with obesity, and are associated with several diseases, including diabetes. Several risk factors in subjects with hypertension are associated with insulin resistance, including low HDL-C and high TG levels and glucose intolerance (29). In this study, we confirmed significant and dose-dependent decreases in TG levels and glucose uptake in mice fed a HFD and boiled tuna extract compared with the mice fed the HFD with no tuna extract (Fig. 1). However, the leptin levels were not affected by the consumption of $100 \mathrm{mg} / \mathrm{kg}$ of tuna extract (Fig. 3A). ALT and AST play important roles in the formation of amino acids in the liver, and their activity increases with HFD-induced liver damage (30,31). Increased ALT and AST activity is also associated with elevated serum cholesterol levels due to complications with bile acid production in liver disorders (32). Therefore, the activity of serum ALT and AST is a useful indicator for determining liver deterioration due to obesity. Our results demonstrated a significant recovery of serum (ALT and AST) and liver (GOT and GPT) enzyme function in the mice fed the tuna extract (Figs. 5 and 6).

$\mathrm{C} / \mathrm{EBP} \alpha$ and PPAR- $\gamma$ induce the expression of each other in a feedback loop, thereby maintaining cell differentiation (33). In vivo studies using mice have demonstrated that the disruption of PPAR $-\gamma$ and C/EBP impairs the formation of white adipose tissue and brown adipose tissue and the differentiation of adipo- cytes (34). This raises the possibility that PPAR- $\gamma$ and C/EBPs may also directly promote adipogenesis- and lipogenesis-related gene expression (16). In this study, the consumption of a HFD upregulated C/EBP and PPAR- $\gamma$ and lipogenic and adipogenic gene expression, whereas the consumption of various concentrations of boiled tuna extract attenuated these effects (Fig. 7). In conclusion, the consumption of a HFD and boiled tuna extract resulted in the restoration of body, liver, and epididymal and abdominal fat weight, as well as serum glucose, TG, TC, HDL-C, LDL-C, insulin, leptin, AST and ALT levels, and in the hepatic SOD and CAT levels, and the levels of various genes involved in adipogenesis and lipogenesis, to levels similar to those of the controls, highlighting its potential anti-obesity effects.

\section{Acknowledgements}

This study was a part of the project titled 'Functional materials and foods using fisheries by-products', funded by the Ministry of Oceans and Fisheries, Korea (20130279).

\section{References}

1. Esser N, Legrand-Poels S, Piette J, Scheen AJ and Paquot N: Inflammation as a link between obesity, metabolic syndrome and type 2 diabetes. Diabetes Res Clin Pract 105: 141-150, 2014.

2. Lei F, Zhang XN, Wang W, Xing DM, Xie WD, Su H and Du LJ: Evidence of anti-obesity effects of the pomegranate leaf extract in high-fat diet induced obese mice. Int J Obes 31: 1023-1029, 2007.

3. Ng M, Fleming T, Robinson M, Thomson B, Graetz N, Margono C, Mullany EC, Biryukov S, Abbafati C, Abera SF, et al: Global, regional, and national prevalence of overweight and obesity in children and adults during 1980-2013: a systematic analysis for the Global Burden of Disease Study 2013. Lancet 384: 766-781, 2014.

4. McPherson K: Reducing the global prevalence of overweight and obesity. Lancet 384: 728-730, 2014.

5. Ritchie SA and Connell JM: The link between abdominal obesity, metabolic syndrome and cardiovascular disease. Nutr Metab Cardiovasc Dis 17: 319-326, 2007.

6. Paccaud F, Schlüter-Fasmeyer V, Wietlisbach V and Bovet P: Dyslipidemia and abdominal obesity: an assessment in three general populations. J Clin Epidemiol 53: 393-400, 2000.

7. Eisinger K, Liebisch G, Schmitz G, Aslanidis C, Krautbauer S and Buechler C: Lipidomic analysis of serum from high fat diet induced obese mice. Int J Mol Sci 15: 2991-3002, 2014.

8. Wang J and Ryu HK: The effects of Momordica charantia on obesity and lipid profiles of mice fed a high-fat diet. Nutr Res Pract 9: 489-495, 2015.

9. Vargas-Robles H, Rios A, Arellano-Mendoza M, Escalante BA, and Schnoor M: Antioxidative diet supplementation reverses high-fat diet-induced increases of cardiovascular risk factors in mice. Oxid Med Cell Longev 2015: 467471, 2015.

10. Koch CE, Lowe C, Pretz D, Steger J, Williams LM and Tups A: High-fat diet induces leptin resistance in leptin-deficient mice. J Neuroendocrinol 26: 58-67, 2014.

11. Yang Y, Li W, Liu Y, Sun Y, Li Y, Yao Q, Li J, Zhang Q, Gao Y, Gao L and Zhao J: Alpha-lipoic acid improves high-fat dietinduced hepatic steatosis by modulating the transcription factors SREBP-1, FoxO1 and Nrf2 via the SIRT1/LKB1/AMPK pathway. J Nutr Biochem 25: 1207-1217, 2014.

12. Gao M, Ma Y and Liu D: High-fat diet-induced adiposity, adipose inflammation, hepatic steatosis and hyperinsulinemia in outbred CD-1 mice. PLoS One 10: e0119784, 2015.

13. Rindler PM, Plafker SM, Szweda LI and Kinter M: High dietary fat selectively increases catalase expression within cardiac mitochondria. J Biol Chem 288: 1979-1990, 2013.

14. Suarez-Jimenez GM, Burgos-Hernandez A and EzquerraBrauer JM: Bioactive peptides and depsipeptides with anticancer potential: sources from marine animals. Mar Drugs 10: 963-986, 2012.

15. Hsu KC, Li-Chan ECY and Jao CL: Antiproliverative activity of peptides prepared from enzymatic hydrolisate of tuna dark muscle on human breast cancer cell line MCF-7. J Food Chem 126: 617-622, 2011. 
16. Kim YM, Kim EY, Kim IH and Nam TJ: Peptide derived from desalinated boiled tuna extract inhibits adipogenesis through the downregulation of C/EBP- $\alpha$ and PPAR- $\gamma$ in 3T3-L1 adipocytes. Int J Mol Med 35: 1362-1368, 2015.

17. Kim YM, Kim IH, Choi JW, Lee MK and Nam TJ: The ant-obesity effects of a tuna peptide on 3T3-L1 adipocytes are mediated by the inhibition of the expression of lipogenic and adipogenic genes and by the activation of the Wnt $/ \beta$-catenin signaling pathway. Int J Mol Med 36: 327-334, 2015.

18. Fasshauer $M$ and Paschke R: Regulation of adipocytokines and insulin resistance. Diabetologia 46: 1594-1603, 2003.

19. Kopelman PG: Obesity as a medical problem. Nature 404: 635-643, 2000

20. Chi MS, Koh ET and Stewart TJ: Effects of garlic on lipid metabolism in rats fed cholesterol or lard. J Nutr 112: 241-248, 1982.

21. Kwon OJ, Kim MY and Roh SS: Improving effect of extract of Ganoderma lucidum in atherosclerosis from LDL receptor knockout mouse. Korea J Herbol 31: 17-23, 2016.

22. Sack FM, Tonkin AM, Craven T, Pfeffer MA, Shepherd J, Keech A, Furberg CD and Braunwald E: Coronary heart disease in patients with low LDL-cholesterol: benefit of pravastatin in diabetics and enhanced role for HDL-cholesterol and triglycerides as risk factors. Circulation 105: 1424-1428, 2002.

23. Scandalios JG: Oxygen stress and superoxide dismutases. Plant Physiol 101: 7-12, 1993.

24. Kim JY, Shin M and Heo YR: Effect of stabilized rice bran on obesity and antioxidative enzyme activity in high fat diet-induced obese C57BL/6 mice. J Korean Soc Food Sci Nutr 43: 1148-1157, 2014.

25. Park PJ, Kim CW, Cho SY, Rha CS, Seo DB and Lee SJ Aqueous spray-dried green tea extract regulates body weight and epididymal fat accumulation in mice. Korean J Food Sci Technol 42: 103-108, 2010.
26. Jeong HJ, Park JH and Kim MJ: Ethanol extract of Hippophae rhamnides L. leaves inhibits adipogenesis through AMP-activated protein kinase (AMPK) activation in 3T3-L1 preadipocytes. Hangug Jaweon Sigmul Haghoeji 28: 582-590, 2015.

27. Friedman JM and Halaas JL: Leptin and the regulation of body weight in mammals. Nature 395: 763-770, 1998.

28. Reaven GM: Banting lecture 1988. Role of insulin resistance in human disease. Diabetes 37: 1595-1607, 1988.

29. Modan M, Halkin H, Almog S, Lusky A, Eshkol A, Shefi M, Shitrit A and Fuchs Z: Hyperinsulinemia. A link between hypertension obesity and glucose intolerance. J Clin Invest 75 : 809-817, 1985.

30. Kang YH, Park YK, Ha TY and Moon KD: Effects of pine needle extracts on serum and liver lipid contents in rats fed high fat diet. J Korean Soc Food Nutr 25: 367-373, 1996.

31. Lim AK, Jung MJ, Kim DW, Hong JH, Jung HK, Kim KS, Kim YH and Kim DI: An extrapolation concentration decision effect antihyperlipidemic of aglycone isoflavone from biotransformation soybean on the fed high-fat diet rats. J Korean Soc Food Sci Nutr 38: 1167-1173, 2009.

32. Rosen ED, Hsu CH, Wang X, Sakai S, Freeman MW, Gonzalez FJ and Spiegelman BM: C/EBPalpha induces adipogenesis through PPARgamma: a unified pathway. Genes Dev 16: 22-26, 2002.

33. Gray SL, Dalla Nora E and Vidal-Puig AJ: Mouse models of PPAR-gamma deficiency: dissecting PPAR-gamma's role in metabolic homoeostasis. Biochem Soc Trans 33: 1053-1058, 2005.

34. Wang ND, Finegold MJ, Bradley A, Ou CN, Abdelsayed SV, Wilde MD, Taylor LR, Wilson DR and Darlington GJ: Impaired energy homeostasis in C/EBP alpha knockout mice. Science 269: 1108-1112, 1995. 